ACTA UNIVERSITATIS WRATISLAVIENSIS

No 3981

Studia nad Autorytaryzmem i Totalitaryzmem 42, nr 1

Wrocław 2020

https://doi.org/10.19195/2300-7249.42.1.3

\author{
PAWEŁ MALENDOWICZ \\ ORCID: 0000-0003-2325-9966
}

Uniwersytet Kazimierza Wielkiego w Bydgoszczy

p.malendowicz@ukw.edu.pl

\title{
Symptomaty antydemokratyzmu w myśli politycznej i aktywności partii radykalnie nacjonalistycznych w Europie na początku XXI wieku. Analiza wybranych przykładów
}

\begin{abstract}
Abstrakt: Autor opisał przejawy antydemokratyzmu myśli politycznej i działalności partii radykalnie nacjonalistycznych w Europie na początku XXI wieku. Demokracja jako system pluralistyczny i tolerancyjny umożliwia bowiem działalność partii politycznych i ruchów społecznych, które łamią zasady demokracji. To jest jej paradoks. Demokracja to pluralizm i tolerancja, a jedną z głównych cech demokracji jest wolność pozytywna. Partie radykalnie nacjonalistyczne również dążą do wolności. Jest to jednak wolność negatywna - wolność od czynników zewnętrznych: innych państw, obcej władzy, korporacji i banków ponadnarodowych, a także od wpływów innych narodów. Elementy te są również charakterystyczne dla innych ruchów antyglobalizacyjnych. Jednak w radykalnym nacjonalizmie cechy te oznaczają zamknięcie się we własnym kraju i wykluczenie innych ludzi z innych grup narodowych. Wskazuje na to totalitarny sposób myślenia radykalnych nacjonalistów, sprzeciw wobec integracji europejskiej, a także podważanie granic państwowych we współczesnej Europie.

Celem artykułu jest ukazanie symptomów antydemokratyzmu w myśli politycznej i działalności radykalnych partii nacjonalistycznych w Europie. Autor przeanalizował dokumenty programowe lub przejawy działalności szesnastu partii i innych organizacji nacjonalistycznych działających w Europie w pierwszych dwóch dekadach XXI wieku; są to: Narodowa Demokracja i Republikański Ruch Społeczny z Hiszpanii, Narodowe Odrodzenie Polski i Obóz Narodowo-Radykalny z Polski, Serbska Partia Radykalna z Serbii, Partia „Ojczyzna” z Rosji, Partia Ludowa Nasza Słowacja ze Słowacji, Prawy Sektor i Wszechukraiński Związek „Swoboda” z Ukrainy, Związek Narodowców z Litwy, Narodowodemokratyczna Partia Niemiec, Jobbik — Ruch na rzecz Lepszych Węgier, Brytyjska Partia Narodowa, Nowa Siła z Włoch, Front Narodowy z Francji oraz Złoty Świt z Grecji. Kryteriami analizy były: stosunek do liberalnej demokracji, koncepcja wolności i suwerenności narodowej, w tym krytyka integracji europejskiej, myślenie totalitarne i gnostyczne, język komunikacji, nielegalne działania i konflikty z prawem, roszczenia terytorialne i groźba nowej wojny w Europie.
\end{abstract}

Słowa kluczowe: radykalny nacjonalizm, partia polityczna, demokracja, krytyka demokracji, integracja europejska.

Studia nad Autorytaryzmem i Totalitaryzmem 42, nr 1, 2020

C for this edition by CNS 
SYMPTOMS OF ANTI-DEMOCRACY IN THE POLITICAL THOUGHT AND THE ACTIVITY OF RADICAL NATIONALIST PARTIES IN EUROPE AT THE BEGINNING OF THE 21ST CENTURY: ANALYSIS OF SELECTED EXAMPLES

\begin{abstract}
The author describes the symptoms of anti-democracy in the political thought and activity of radical nationalist parties in Europe at the beginning of the 21 st century. Democracy, as a pluralist and tolerant system, enables the activity of political parties and social movements that break the principles of democracy. This is the paradox of democracy. Democracy is pluralism and tolerance. One of the main features of democracy is positive freedom. Radical nationalist parties also want to achieve freedom. However, it is negative freedom - it is freedom from external factors: other states, foreign power, corporations and transnational banks, as well as freedom from the influence of other nations. These elements are also characteristic of other anti-globalisation movements. In radical nationalism, however, these traits mean being locked up in your own country and excluding other people from other national groups. This is demonstrated by the totalitarian way of thinking of radical nationalists, opposition to European integration, as well as undermining national borders in contemporary Europe. The aim of the article is to show the symptoms of anti-democracy in the political thought and the activity of radical nationalist parties in Europe. The author analysed the program documents or the manifestations of activity of 16 parties and other type of nationalist organisations operating in Europe in the first two decades of the 21st century: The National Democracy and Republican Social Movement from Spain, National Rebirth of Poland and National Radical Camp from Poland, The Serbian Radical Party from Serbia, The Motherland Party from Russia, The People's Party - Our Slovakia from Slovakia, The Right Sector and All-Ukrainian Union "Svoboda" from Ukraine, The Nationalist Union from Lithuania, The National Democratic Party of Germany, The Jobbik Movement for a Better Hungary, The British National Party, The New Force from Italy, The National Front from France, and Golden Dawn from Greece. The criteria for the analysis were attitudes to liberal democracy, the concept of freedom and national sovereignty, including criticism of European integration, totalitarian and gnostic type of thinking, language of communication, illegal activities and conflicts with law, territorial claims and the threat of a new war in Europe.
\end{abstract}

Keywords: radical nationalism, political party, democracy, critique of democracy, European integration.

Demokracja jest formą organizacji stosunków społecznych i systemem politycznym, w którym wolności obywatelskie są określone prawem, władza jest legitymizowana przez rywalizacyjne wybory, społeczeństwo dysponuje możliwością sprawowania kontroli nad rządzącymi poprzez instytucje do tego powołane, organizacje obywatelskie i media, istnieje rotacja rządzących grup politycznych, relatywizm, otwartość i tolerancja dla inaczej myślących ludzi, a także typ mentalności społecznej niesprzeczny z zasadami demokracji. Demokracja to także spontaniczna i autentyczna aktywność obywatelska w skali masowej, pluralizm, w tym alternatywność wyborów, policentryzm, którego przejawem jest rozdzielenie ośrodków kierowniczych właściwych różnym dziedzinom życia społecznego. To wreszcie uzgadnianie zróżnicowanych interesów i poglądów między wielkimi 
grupami społecznymi i ich reprezentacjami, służące dobru wspólnemu ${ }^{1}$. Demokracja opiera się na koncepcji suwerenności narodu obywatelskiego, racjonalizmie i antydogmatyzmie myślenia politycznego, wolności religijnej, koncyliacyjnym i pozbawionym przemocy języku komunikowania, szacunku wobec prawa oraz pokojowym współistnieniu państw i narodów.

Demokracja jako system pluralistyczny i tolerancyjny dopuszcza jednak możliwość istnienia partii politycznych i ruchów społecznych, które podważają jej zasady. Kierowane wobec takich organizacji oskarżenia o niedemokratyczność i ustanawiane zakazy ich działalności mogą powodować reakcje zwrotne. Partie i ruchy delegalizowane mogą wówczas oskarżać organy państwa oraz instytucje kontrolne i sądowe państw demokratycznych o niedemokratyczność podejmowanych decyzji, w tym o ograniczanie pluralizmu, który jest przecież cechą demokracji.

Jedną z rodzin partii politycznych, które korzystają z luk i paradoksów demokracji, podejmując zgodną z prawem aktywność polityczną, jest rodzina partii nacjonalistycznych o predylekcjach radykalnych. Ich radykalizm przejawia się nie tylko w skrajności nacjonalistycznej myśli politycznej, w tym programów politycznych, lecz przede wszystkim w bezkompromisowości, która wyklucza konsensus polityczny i redukuje zdolności współpracy z innymi organizacjami akceptującymi zasady współczesnej demokracji. Te cechy stanowią podstawowy element mechanizmu funkcjonowania demokracji, bez którego jej istnienie jest niemożliwe. Radykalizm analizowanego nacjonalizmu to także interpretowanie takich wartości jak naród czy demokracja, opierając się na fundamentalizmie eksplanacyjnym tych terminów, który uniemożliwia refleksję nad nimi, tworząc ich gotowe obrazy w procesie myślenia politycznego.

Celem artykułu jest wskazanie elementów programów politycznych partii radykalnie nacjonalistycznych, przykładów enuncjacji ich liderów i przejawów ich działalności, które mogą wskazywać na przekraczanie lub łamanie zasad właściwych demokratycznemu państwu prawnemu i organizacji społeczeństwa demokratycznego $^{2}$. Zostały one określone jako symptomaty (zwiastuny albo oznaki) antydemokratyzmu myśli i przejawów aktywności tych organizacji. Posłużyły do sformułowania pytania: czy myśl nacjonalistyczna interpretowana radykalnie, a także wybrane przejawy aktywności partii oraz innych organizacji nacjonalistycznych mogą świadczyć o deficytach ich demokratyczności? Odpowiadając na to pytanie, autor zastosował krytyczną analizę dokumentów programowych szesnastu partii i innego typu organizacji nacjonalistycznych działających w Europie w pierwszych dwóch dekadach XXI wieku. Została ona poparta przykładami działalności liderów wybranych partii i stowarzyszeń, ich członków oraz akolitów. Nie znaczy to jednak,

${ }^{1}$ M. Karwat, Kryteria demokratyzmu postaw spolecznych, stosunków politycznych i państwa, „Społeczeństwo i Polityka” 1 (2), 2005, s. 50-62.

${ }^{2}$ Zob. też P. Malendowicz, Radykalna myśl polityczna a bezpieczeństwo europejskich demokracji. Przykład nacjonalizmu antysystemowego, „Rocznik Integracji Europejskiej” 13, 2019, s. 73-84.

Studia nad Autorytaryzmem i Totalitaryzmem 42, nr 1, 2020

(C) for this edition by CNS 
że autor zamierzał wskazać konkretne partie jako antydemokratyczne. Analiza dotyczy symptomatów antydemokratycznych tendencji, mogących się kształtować albo rozwijających się w tej rodzinie politycznej.

Analizie zostały poddane programy, enuncjacje i działalność następujących ugrupowań: Democracia Nacional (Narodowa Demokracja) i Movimiento Social Republicano (Ruch Społeczno-Republikański) z Hiszpanii, Narodowe Odrodzenie Polski i Obóz Narodowo-Radykalny z Polski, Srpska radikalna stranka (Serbska Partia Radykalna) z Serbii, Partija „Rodina” (Partia „Ojczyzna”) z Rosji, L’udová strana Naše Slovensko (Partia Ludowa Nasza Słowacja) ze Słowacji, Pravyi sektor (Prawy Sektor) i „Svoboda” (,Swoboda”) z Ukrainy, Tautininkų sajunga (Związek Narodowców) z Litwy, Nationaldemokratische Partei Deutschlands (Narodowodemokratyczna Partia Niemiec) z Niemiec, Jobbik Magyarországért Mozgalom (Jobbik — Ruch na rzecz Lepszych Węgier) z Węgier, British National Party (Brytyjska Partia Narodowa) z Wielkiej Brytanii, Forza Nuova (Nowa Siła) z Włoch,

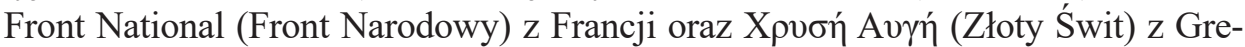
$\mathrm{cji}^{3}$. Większość $\mathrm{z}$ nich miała swoje reprezentacje $\mathrm{w}$ parlamentach krajowych lub Parlamencie Europejskim. Autor dokonał ich wyboru losowo, z uwzględnieniem kryterium ich obecności w różnych częściach kontynentu oraz na podstawie subiektywnej analizy treści negatywnych (krytycznych) i pozytywnych (prospektywnych) warstw ich programów, a także stosowanej retoryki i ewentualnych przejawów aktywności, świadczących o ich radykalizmie. Kierowanie się ściśle wyznaczonymi kryteriami doboru materiału badawczego, jakkolwiek niezbędne do analizy opartej na kryteriach poprawności metodologicznej w badaniach stanów zastanych (tego, co jest), byłoby przeszkodą w realizacji funkcji nauki, polegającej na sygnalizowaniu możliwości wystąpienia tendencji (tego, co może być), których dostrzegalne są zwiastuny albo pojedyncze i niespecyficzne objawy. Analiza została przeprowadzona na podstawie kryteriów, które autor sformułował, wskazując elementy antydemokratyzmu myśli politycznej i wybranych form aktywności organizacji nacjonalistycznych. Kryteria te zostały określone w kolejnych częściach artykułu. Są nimi: nacjonalistyczne oceny demokracji liberalnej, koncepcja wolności i suwerenności narodowej, w tym krytyka integracji europejskiej, totalitarny i gnostyczny typ myślenia, język komunikowania, działania nielegalne i konflikty z prawem oraz roszczenia terytorialne i zagrożenie nową wojną w Europie.

\section{Nacjonalistyczne oceny demokracji liberalnej}

Niemal wszystkie z analizowanych programów partii politycznych krytykowały liberalne demokracje jako systemy, które w istotny sposób przyczyniają

3 Szerzej o programach tych partii zob. P. Malendowicz, $W$ drodze do władzy... Nacjonalistyczne projekty państw Europy XXI wieku, Bydgoszcz 2017.

Studia nad Autorytaryzmem i Totalitaryzmem 42, nr 1, 2020

(C) for this edition by CNS 
się do rozpadu tradycyjnych wspólnot narodowych. Nacjonaliści wskazywali na takie ich cechy, jak: indywidualizm, konsumpcjonizm, materializm, amoralizm i nihilizm. Poza tym francuski Front Narodowy podnosił, że demokracja we współczesnych państwach jest ograniczana przez instytucje i procedury niezgodne $\mathrm{z}$ imperatywem właściwym demokracji, a także przez nadużywanie władzy i stawianie zysku ponad dobro ogółu. Na deficyt demokracji wpływają również instytucje europejskie - niewybieralne i technokratyczne, jak Komisja Europejska. Front Narodowy podkreślał, że wymuszone kształtowanie pojęcia „naród europejski” sankcjonuje byt, który nie istnieje. Działania przeciwko suwerenności narodu francuskiego nacjonaliści nazwali zbrodnią i symbolem pogardy dla demokracji ze strony parlamentarzystów francuskich. Front negatywnie oceniał procedury wyborcze we Francji, ograniczanie swobody wypowiedzi przed wyborami oraz wybory większościowe, które części wyborców nie pozwalały wprowadzić swoich przedstawicieli do parlamentu. Partia ta krytycznie oceniła nieczęstą organizację referendów, a także ignorowanie woli obywateli wyrażonej w ramach tej formy podejmowania decyzji. W opinii tej partii również same relacje polityczne nabrały charakteru sprzecznego z ideałami demokratycznymi, przez co należy rozumieć niewywiązywanie się z obietnic wyborczych przez polityków 4 .

Grecki Złoty Świt uznawał za fałszywe podziały na lewicowość i prawicowość właściwe demokracji. Chwalił system ludowy jako pożądany; w nim władza polityczna miała być właściwa ludowi. Uznawał, że przedstawicieli partii politycznych charakteryzowała przekupność woli, a lud miał rządzić samym sobą,

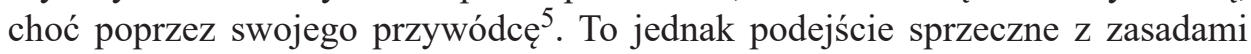
demokracji jako systemu myślenia społecznego.

Narodowa Demokracja z Hiszpanii w swoim programie analizowała etymologię terminu „demokracja” i jego współczesny kontekst. Miała ona opierać się na oświeceniowym rozumieniu takich terminów, jak „wolność”, „suwerenność”, „prawa człowieka”, ,praworządność”, które miały nawiązywać do nowoczesnej racjonalności, rozumianej jako autonomia, czyli wolność „od”. Według nacjonalistów to nie jednostka powinna być uznawana za cel najwyższy. Indywidualizm uniemożliwia bowiem działalność dla dobra ogółu. Narodowa Demokracja krytykowała utratę suwerenności narodu na rzecz elit ekonomicznych, politycznych i intelektualnych działających na poziomie ponadnarodowym. Partia ta uznała, że epoka nowoczesnego racjonalizmu to okres kryzysu etycznego i duchowego. $\mathrm{Na}$ skutek dziedzictwa oświeceniowego autonomia woli jednostki została podniesiona do rangi celu autotelicznego; natomiast miała być ona środkiem do osiągnięcia

${ }^{4}$ Front National, Notre Projet - Programme Politique du Front National, 2012, http://www. frontnational.com/le-projet-de-marine-le-pen/ (dostęp: 28.06.2016).

5 Golden Dawn, What Being a Golden-Dawner Means, http://www.xryshaygh.com/en/information (dostęp: 28.06.2016).

Studia nad Autorytaryzmem i Totalitaryzmem 42, nr 1, 2020

(C) for this edition by CNS 
celu $^{6}$. Nacjonaliści z Narodowej Demokracji zanegowali pozbawienie demokracji treści i jej oparcie na abstrakcyjnych jednostkach. Odrzucili zatem ,plutokrację" i „partiokrację" demokracji. Zanegowali formę liberalną i prawno-polityczną demokracji, pojmowaną jako prosty porządek jurydyczny, jej postać pustą, a więc taką, która nie została osadzona w narodzie (a każda forma potrzebuje materii). Narodowa Demokracja chciała większej partycypacji i równości szans do realizacji interesów ludu hiszpańskiego ${ }^{7}$.

Z kolei Ruch Społeczno-Republikański wzywał do reformy konstytucyjnej w Hiszpanii. Uznał, że ukształtowanie się współczesnego systemu politycznego w tym państwie było skutkiem konsensusu między spadkobiercami dyktatury generała Franco i opozycją a ośrodkami międzynarodowymi ${ }^{8}$. Podobne oceny, ale w odniesieniu do innych państw, były właściwe nacjonalistom z krajów, które do końca lat osiemdziesiątych XX wieku znajdowały się w strefie wpływów Związku Radzieckiego.

Nowa Siła z Włoch w swoim programie odniosła się natomiast do historii państwa i narodu. Chciała unieważnienia prawa dotyczącego karania za propagandę faszystowską (prawo Mancino) ${ }^{9}$, które uznała za ograniczanie demokracji.

Postulaty odbudowy suwerenności narodowej były nadrzędnymi w programie Narodowodemokratycznej Partii Niemiec. Dla tej partii wszelka władza wywodzi się od narodu rozumianego jako wspólnota. Państwo ponosi odpowiedzialność za cały naród i dlatego nie kieruje się interesami poszczególnych grup ${ }^{10}$. Tymczasem we współczesnym państwie demokratycznym państwo (władza) dąży do uzgadniania sprzecznych interesów, co jest cechą polityki państwa demokratycznego. Nie narzuca ono woli w imię całości narodowej, co jest sprzeczne $\mathrm{z}$ demokracją per se.

Również Narodowe Odrodzenie Polski zanegowało liberalną demokrację. Według lidera tej partii — Adama Gmurczyka —

demokracja, a przynajmniej to, co się dzisiaj pod słowem tym rozumie, jest nie mniej dla Narodu zabójcza niż „dyktatura ludu pracującego miast i wsi”. Inne są metody, które systemy te stosują, lecz cele, do których dążą, są identyczne: zniszczenie narodowej i ludzkiej wolności,

6 Democracia Nacional, Programa Democracia Nacional, [w:] Documentos Ideológicos y Programáticos de Democracia Nacional, http://democracianacional.org/dn/conocenos/ (dostęp: 27.10. 2016).

7 J. Bartyzel, Między katolickim panhiszpanizmem a separatyzmem etnicznym i suwerenizmem. Aporematyczność pojęcia „nacjonalizm” w Hiszpanii, [w:] Współczesne nacjonalizmy, red. M. Jeziński, Toruń 2008, s. 265.

8 Movimiento Social Republicano, Programa político. 300 medidas para cambiar España, http://msr.org.es/nosotros/programa-politico (dostęp: 11.12.2016).

9 Forza Nuova, 8 Punti, http://www.forzanuova.eu/?page id=542 (dostęp: 4.12.2016).

10 Nationaldemokratische Partei Deutschlands, Arbeit. Familie. Vaterland. Das Parteiprogramm der Nationaldemokratischen Partei Deutschlands, http://www.npd.de/themen/ (dostęp: 9.12.2014).

Studia nad Autorytaryzmem i Totalitaryzmem 42, nr 1, 2020

(C) for this edition by CNS 
stworzenie społeczeństwa niewolniczego, pozbawionego tych wszystkich cech, które składają się na to, co potocznie nazywamy Człowieczeństwem — Wiary, Tradycji, Honoru ${ }^{11}$.

Prawy Sektor na Ukrainie postulował narodokrację jako nowy system władzy. Jednakże naród w narodokracji miał być skonstruowany hierarchicznie, a na jego szczycie miały stać osoby o szczególnych cechach ${ }^{12}$.

Należy w tym miejscu podkreślić, że cechą demokracji jest pluralizm. Partie nacjonalistyczne w swoich programach traktowały go jednak instrumentalnie. Żądały pluralizmu na etapie prób zaistnienia i walki o osiągnięcie zdolności rządzenia. Chciały dostępu do mediów i możliwości udziału w wyborach (nawet w sytuacji braku realnego poparcia dla tych partii). Natomiast po osiągnięciu zdolności władczych niektóre z tych partii proponowały system władzy opartej na narodzie lub jednostce albo partii przewodzącej narodowi. Pluralizm w liberalnych demokracjach traktowany był także przez nie jako wartość fikcyjna. Był wielością i różnorodnością w ramach jednej narracji, narzuconej przez dominujące media, system edukacyjny albo szerzej — system propagandy dominujących ośrodków władzy ponadnarodowej: europejskiej, korporacyjnej i finansowej, które promowały typ demokracji liberalnej. W ich opinii to typ $\mathrm{w}$ istocie niedemokratyczny, ograniczający wolność narodu, a w związku z tym wzmagający reakcje przeciwne, na rzecz wolności „od” zewnętrznych ograniczeń.

\section{Koncepcja wolności i suwerenności narodowej}

Wolność w ujęciu nacjonalistycznym była interpretowana inaczej niż wolność właściwa demokracjom liberalnym. Wolność w myśli politycznej nacjonalizmu to wolność kolektywna, a zarazem wolność negatywna — wolność „od”. Natomiast współczesne demokracje charakteryzuje wolność w ujęciu indywidualistycznym i wolność pozytywna — wolność „do”. Istotę kolektywnej wolności w swoim programie podkreślił Prawy Sektor, który odwoływał się do niemieckiego ekonomisty z XIX wieku Friedricha Lista: „Tylko tam, gdzie interesy jednostki są podporządkowane interesom narodu, gdzie jedno pokolenie po drugim walczą o jeden wspólny cel, naród osiągnął harmonijny rozwój sił wytwórczych"13.

Dla nacjonalistów litewskich każdy naród jest suwerenem politycznym w swojej historycznej i etnicznej ojczyźnie. Ta suwerenność interpretowana była przez nich jako wolność negatywna. Według nich naród sam podejmuje decyzje o utworzeniu własnego państwa narodowego, dlatego litewscy nacjonaliści deklarowali wsparcie dla innych narodów do tworzenia własnych organizmów

11 Cyt. za: M. Lewandowski, Na szlaku idei. Nacjonalizm Narodowego Odrodzenia Polski w świetle publikacji pisma ,,Szczerbiec”, Warszawa 2014, s. 20-21.

12 Pravyi sektor, Programa partii „Pravyi sektor”, http://pravyysektor.info/programa.html (dostęp: 22.09.2016).

13 Ibidem; jeśli nie podano inaczej, przeł. P.M.

Studia nad Autorytaryzmem i Totalitaryzmem 42, nr 1, 2020

(C) for this edition by CNS 
państwowych, obrony niepodległości, integralności terytorialnej, tożsamości narodowej i obywatelskiej ${ }^{14}$.

Idea wolności kolektywnej i wolności negatywnej znalazła wyraz także w programie hiszpańskiej Narodowej Demokracji. Według niej wolność zbiorowa przejawia się w zdolności narodu do decydowania o swoim losie, a więc w jego suwerenności ${ }^{15}$.

\section{Sprzeciw wobec Unii Europejskiej}

Jednym z przejawów koncepcji nacjonalistycznej suwerenności jest wskazanie „wroga narodu”, który ogranicza jego wolność. W programach partii nacjonalistycznych wrogami były korporacje ponadnarodowe, obca i międzynarodowa finansjera, inne państwa (szczególnie mocarstwa) oraz inne narody, w tym imigranci. Często wskazywanym wrogiem była jednak Unia Europejska, jej instytucje i polityczne elity. Sam sprzeciw wobec integracji europejskiej nie oznacza jednak jeszcze antydemokratyczności nacjonalistów a priori. Jeśli zaś jest połączony z innymi elementami negacji demokracji i koncepcją kolektywnej wolności negatywnej, stanowi symptomat antydemokratyzmu, a traktowany autonomicznie jest symptomatem niespecyficznym i niekoniecznym. Należy także dodać, że Unia Europejska została zbudowana na wartościach demokratycznych. Dlatego też sprzeciw wobec niej może być traktowany jako podważanie demokracji albo wskazywanie deficytów jej demokratyczności, które powinny służyć reformom Unii w ramach procesu demokratyzacji.

Francuski Front Narodowy wskazywał, że Unia Europejska to organizacja podążająca w niewłaściwym kierunku. Została utworzona przez kraje kultur sąsiadujących z sobą, gdy były one na porównywalnym poziomie rozwoju ekonomicznego. Przez jej poszerzanie kierunek integracji europejskiej się zmienił. Według nacjonalistów traktaty unijne zakazały państwu jakiejkolwiek formy patriotyzmu gospodarczego. Partia ta zapisała w programie, że UE cierpi na „deficyt demokracji”. Potwierdzeniem tego miał być przykład narodów głosujących przeciwko projektowi Konstytucji Europejskiej. Nadto istotną rolę w Unii odgrywa Komisja, która jest organem niewybieralnym. Przekazuje ona technokratom obszerne uprawnienia. Decyzje Europejskiego Banku Centralnego również mają charakter despotyczny. Wybory powszechne eurodeputowanych maskują tę niedemokratyczność. Parlament, w porównaniu z Komisją, ma wciąż zbyt małe uprawnienia. Także inicjatywy obywatelskie nie odgrywają istotnej roli w kierowaniu Unią. Front Narodowy ocenił, że Wspólna Polityka Rolna doprowadziła do zmarginalizowania europejskiego rolnictwa, a euro i otwarcie granic na obcą

14 Tautininkų sajunga, Bendroji programa, http://www.tautininkai.lt/programos/bendroji-progr ama-2016-m/ (dostęp: 19.09.2016).

15 Democracia Nacional, op. cit.

Studia nad Autorytaryzmem i Totalitaryzmem 42, nr 1, 2020

(C) for this edition by CNS 
konkurencję doprowadziły do utraty milionów miejsc pracy w sektorze przemysłowym, recesje w strefie euro trwają dłużej, a pieniądze na ugaszenie pożaru w Grecji ,poszły z dymem” 16 .

Na podstawie tych argumentów Front Narodowy chciał zainicjować renegocjacje traktatów europejskich - przyszła Europa miała opierać się na suwerenności narodów, tożsamości, języków i kultur. Proces przywracania narodowej niezależności miało koordynować Ministerstwo Suwerenności. Front uznał za konieczne kontrolowanie granic w obrębie stowarzyszenia państw europejskich o podobnych interesach, odzyskanie kontroli nad polityką monetarną i finansami, przywrócenie nadrzędności prawa krajowego nad prawem unijnym, zainicjowanie projektów europejskich, opierających się na dobrowolnym partnerstwie oraz anulowanie składki netto Francji do budżetu europejskiego. Te postulaty stanowiły dla francuskich nacjonalistów drogowskaz do „wyswobodzenia się" spod nadzoru eurokratycznego superpaństwa ${ }^{17}$. Europa, ale nie Unia Europejska, miała respektować suwerenność narodów i być Europą Wolnych Narodów ${ }^{18}$, w której „Niemcy powinni być niemieccy”, a „Włosi — włoscy”19.

Również hiszpańska Narodowa Demokracja proponowała budowę Konfederacji Europejskiej, zachowującej suwerenność narodów, ale i tożsamość europejską potrzebną do osiągania wspólnych celów jednego bloku geopolitycznego ${ }^{20}$. Ruch Społeczno-Republikański określił w programie cel, jakim było przyjęcie konstytucji, w której zapisane zostałyby prawa narodów Europy ${ }^{21}$.

Narodowodemokratyczna Partia Niemiec odrzuciła konstytucję Unii Europejskiej i sprzeciwiała się zrzeczeniu suwerenności Niemiec na rzecz Unii Europejskiej. Uznała, że przeniesienie kompetencji rządu i landów do Unii Europejskiej doprowadziło do upadku suwerenności narodowej. Według niej niemiecka klasa polityczna emigruje do Europy, w której władza wykonawcza nie ma demokratycznej legitymacji. Taką Unię nazwała Europą technokratów i koncernów istniejącą przeciw Europie narodów ${ }^{22}$.

Narodowe Odrodzenie Polski w dokumencie zatytułowanym Zasady programowe uznało, że dąży do budowy ładu narodowo-państwowego opartego na dziedzictwie cywilizacji łacińskiej, którego zasadniczymi elementami są między innymi:

16 Front National, op. cit.

17 Ibidem.

18 Marine Le Pen: Europa Wolnych Narodów zastapi UE!, 15.11.2016, http://www.nacjonalista. p1/2016/11/15/marine-le-pen-europa-wolnych-narodow-zastapi-ue/ (dostęp: 2.11.2017).

19 J.M. Le Pen, Nadzieja. Rozważania o Francji i Europie z przywódca francuskiego Frontu Narodowego, przeł. M. Miszalski, Warszawa 1994, s. 93.

20 Democracia Nacional, op. cit.

21 Movimiento Social Republicano, op. cit.

22 Nationaldemokratische Partei Deutschlands, op. cit.

Studia nad Autorytaryzmem i Totalitaryzmem 42, nr 1, 2020

(c) for this edition by CNS 
— wprowadzenie zakazu działania grup, organizacji, partii, ośrodków informacji i propagandy uprawiających polityczną prostytucję na rzecz obcych państw i istniejących poza Krajem struktur władzy — w pierwszym rzędzie dotyczy to tych, którzy prowadzą akcję na rzecz likwidacji Państwa Polskiego i wchłonięcia go przez Unię Europejską;

— natychmiastowe zerwanie wszelkich działań ,integracyjnych” z Unią Europejską, prowadzących do likwidacji Państwa Polskiego. [...] nasz kraj może i powinien wiązać się układami polityczno-gospodarczymi z innymi strukturami zewnętrznymi, ale tylko i wyłącznie na warunkach partnerskich oraz zgodnie $\mathrm{z}$ naszymi interesami; niedopuszczalne jest natomiast, by ceną jakichkolwiek układów międzypaństwowych była utrata niezależności Polski jako państwa ${ }^{23}$.

Z kolei Obóz Narodowo-Radykalny za swój ideowy fundament postanowił przyjąć ,sprzeciw wobec narzucenia przez rządy panujące na terenie Unii Europejskiej i jej członków modelu społeczeństw multikulturowych, jako z gruntu fałszywego i niebezpiecznego" 24 .

\section{Myślenie totalitarne i gnostyczne}

Koncepcja wolności i suwerenności w myśli radykalnie nacjonalistycznej jest elementem myślenia charakterystycznego dla totalitarnej gnozy politycznej. Radykalni nacjonaliści wierzą, że poznali prawdę o zbawieniu, które może dokonać się w świecie rzeczywistym, tu i teraz. Ich myślenie to kreowanie bytu nieistniejącego, wyobrażonego, a więc idealnego narodu, który ma zadanie zbawienia się, kiedy już składać się będzie z nowego typu ludzi. To wreszcie dzielenie świata na strefy dobra i zła. Wszystkie dobre wydarzenia dzieją się w świecie dobra, a złe w świecie nienarodowego chaosu: demokracja, globalizacja, konsumpcjonizm, patologie społeczne, rozluźnienie moralne. Istnieje zatem prawda radykalnego nacjonalizmu i prawda dla kosmopolitów. Myślenie totalitarne i gnostyczne to także nadinterpretacja historii, prymat celu nad moralnością, ocenianie człowieka przez pryzmat jego możliwości uczestnictwa w zbawieniu (a więc kryteria narodowe i lojalność wobec narodu lub jego elity), a także definiowanie wyznawcy jako bojownika, który zdobył wiedzę o zbawieniu ${ }^{25}$.

Grecki Złoty Świt potraktował nacjonalizm jako ideę, która rodzi nowe i prawdziwe wartości etyczne, duchowe i społeczne. Z kolei tocząca się w nieprawdziwym świecie walka między lewicą a prawicą została uznana przez tę partię za teatr, w którym aktorzy przedłużają stan dominacji antynarodowych i kosmopolitycznych sił na świecie. Według Złotego Świtu

23 Narodowe Odrodzenie Polski, Zasady programowe, http://www.nop.org.pl/zasady-programowe/ (dostęp: 25.11.2019).

24 Obóz Narodowo-Radykalny, Deklaracja ideowa, https://www.onr.com.pl/deklaracja-ideowa/ (dostęp: 16.01.2017).

25 R. Bäcker, Nietradycyjna teoria polityki, Toruń 2011, s. 191-193.

Studia nad Autorytaryzmem i Totalitaryzmem 42, nr 1, 2020

(C) for this edition by CNS 
znaczenie ma społeczność, grupa, Lud, a nie pojedyncza jednostka. Jednostka staje się osobą i zyskuje kształt, rozwija swoje wewnętrzne ,ja” pośród „my” większej zbiorowości. Jednostki nie mają znaczenia historycznego w przeciwieństwie do osób, które należy postrzegać jako ludzi koncentrujących w sobie wyjątkowe cechy służące Ludowi i Narodowi. Osobą w tym pojęciu może stać się tylko jednostka, która wypełnia swój cel społeczny za pomocą swoich zdolności, na które wpływ mają wyznawane przez nią wartości społeczne i osobiste. Ten najwyższy rodzaj człowieka jest nowym gatunkiem człowieka i to właśnie takiego człowieka pragnie stworzyć idea Nacjonalizmu ${ }^{26}$.

Podobne deklaracje programowe składał ukraiński Prawy Sektor. W jego koncepcji władza miała być relacją w ramach hierarchicznie skonstruowanego narodu i miała być sprawowana za pośrednictwem przedstawicieli charakteryzujących się szczególnymi cechami: zdolnościami, altruizmem i ideowością ${ }^{27}$.

Narodowe Odrodzenie Polski w swoim przekazie ideologicznym, dokumentach i publicystyce kreowało wzory osobowe swoich zwolenników jako patriotów, bohaterów i osób głęboko wierzących, dla których Dekalog miał być wyznacznikiem stylu życia ${ }^{28}$.

Również węgierscy nacjonaliści z partii Jobbik wierzyli, że etyczne umocnienie narodu węgierskiego może być oparte tylko na nauce Chrystusa. W tym odnowieniu życia społecznego szczególna rola przypada Kościołom chrześcijańskim. Miały one być podstawą duchową i kulturową dla narodu. Dla partii Jobbik, podobnie jak dla polskich nacjonalistów, tożsamość narodowa i chrześcijaństwo stanowiły pojęcia nierozłączne ${ }^{29}$.

Symboliczne odniesienia do chrześcijaństwa można odnaleźć również w historii włoskiej Nowej Siły. Powstała ona w dniu, w którym czczono Archanioła Michała $^{30}$, który sprzeciwił się Lucyferowi, buntującemu inne anioły i występującemu przeciwko Bogu. To symboliczna identyfikacja nacjonalizmu z siłą dobra przeciwstawiającą się siłom zła.

Partie nacjonalistyczne $\mathrm{z}$ reguły jednak traktowały religię nie jako element myślenia gnostycznego, umożliwiającego poznanie prawdy i zbawienie, lecz jako instrument służący narodowi. Roberto Fiore - lider włoskich nacjonalistów z Nowej Siły — na forum europejskim krytykował polityków za antykościelne wypowiedzi, oskarżając ich o tworzenie atmosfery nietolerancji wobec katolicyzmu $^{31}$. Ta jednak miała petryfikować nacjonalistów-katolików i jednoczyć ich

26 Golden Dawn, op. cit.

27 Pravyi sektor, op. cit.

28 G. Radomski, Puryfikacja czy instrumentalizacja? Narodowe Odrodzenie Polski wobec kanonu kultury narodowej, [w:] Współczesne nacjonalizmy, red. M. Jeziński, Toruń 2008, s. 67.

29 Jobbik Magyarországért Mozgalom, Alapitó Nyilatkozat, 24.10.2003, https://jobbik.hu/rovatok/egyeb/alapito_nyilatkozat (dostęp: 14.02.2017).

30 Forza Nuova, Chi siamo, http://www.forzanuova.eu/?page_id=103 (dostęp: 4.12.2016).

31 R. Fiore, Sumienie europejskie i totalitaryzm, wypowiedź w debacie w Parlamencie Europejskim, Strasburg, 25.03.2009, http://www.europarl.europa.eu/sides/getDoc.do?pubRef=-//EP// TEXT+CRE+20090325+ITEM-010+DOC+XML+V0//PL\&language=pl\&query=INTERV\&detail=3-392 (dostęp: 17.01.2017).

Studia nad Autorytaryzmem i Totalitaryzmem 42, nr 1, 2020

(C) for this edition by CNS 
wokół idei narodowej. Serbska Partia Radykalna zaś w swoim programie nie kryła instrumentalnego traktowania Kościoła pełniącego funkcje integracyjne wobec narodu $^{32}$.

Należy jednak zaznaczyć, że symptomat antydemokratyzmu, jakim jest myślenie totalitarne i gnostyczne, nie jest tożsamy z przekazem programowym i przejawami aktywności wszystkich partii radykalnie nacjonalistycznych, może bowiem także stanowić ukrytą strukturę, nieujawnianą w przekazie programowym i sposobach aktywności tych organizacji politycznych. W tym wypadku nie jest jednak możliwe poprawne zweryfikowanie występowania tego symptomatu bez zastosowania obserwacji uczestniczącej jako metody pozwalającej na ocenę sposobów myślenia grupy badanej przez uczestnictwo w niej. Niemniej wspólne dla radykalnego nacjonalizmu jest formułowanie ocen świata współczesnego w kategoriach esencjalnie negatywnych, upatrywanie w narodzie możliwości kreacji nowej, lepszej przyszłości i kreślenie koncepcji człowieka spełniającego warunki uczestnictwa w aktywnym życiu społecznym służącym narodowi. Tego typu myślenie opiera się na upatrywaniu w narodzie ,pożądanego ideału”, tworzonego przez partyjne elity, wszak sam naród w demokracji liberalnej nie jest i nie może być idealny, a „pożądany ideał” może zostać osiągnięty tylko w państwie rządzonym przez partię nacjonalistyczną. Partia nacjonalistyczna chce odgrywać rolę służebną wobec narodu i być jednocześnie jego awangardą, która kształtuje naród, ponieważ ma wiedzę o tym narodzie. Paradoks polega na tym, że kult mistycznego narodu stoi w sprzeczności do tego, że naród nie może sprostać wymaganiom swoich czcicieli ${ }^{33}$.

\section{Język komunikowania}

Komunikowanie, a w tym wypadku komunikowanie polityczne, przebiega w obrębie triady: elity polityczne i obywatele, czyli wyborcy, między nimi zaś znajdują się zwykle media - występujące jako pośrednik ${ }^{34}$. To właśnie za pośrednictwem mediów, w tym prasy drukowanej, a współcześnie częściej internetu, odbiorcy doświadczają języka używanego przez partie radykalnie nacjonalistyczne. Charakterystyczna dla niego jest nowomowa, którą Umberto Eco uznał za jedną z czternastu cech „wiecznego faszyzmu"35.

32 Srpska radikalna stranka, Program, http://www.srpskaradikalnastranka.org.rs/program/44 (dostęp: 7.01.2015).

33 A. Durska, Podwójna jaźń polskiego nacjonalizmu, [w:] Paradoksy polityki, red. M. Karwat, Warszawa 2007, s. 235.

34 J. Garlicki, Komunikowanie polityczne - od kampanii wyborczej do kampanii permanent$n e j$, ,Studia Politologiczne” 16, 2010, s. 26-27.

35 U. Eco, Ur-fascism, „The New York Review of Books” 22.06.1995, s. 8.

Studia nad Autorytaryzmem i Totalitaryzmem 42, nr 1, 2020

(C) for this edition by CNS 
Dla przykładu, słowaccy nacjonaliści podwyżki podatków nazywali „grabieżą państwa”, sprawujących władzę „złodziejami z rządu”, prywatyzację „największą zbrodnią”, działalność międzynarodowych banków w Słowacji „niewolą”, a działania przeciwko nim „wyzwoleniem”, Cyganów „,pasożytami”, NATO „organizacją przestępczą”, a władzę instytucji unijnych „brukselskim dyktatem”36. Francuski Front Narodowy ustami Marine Le Pen Unię Europejską określił jako „opresyjny model”37, „,więzienie narodów”38 i ,swego rodzaju Związek Sowiecki Europy”39, podczas gdy społeczeństwo multikulturowe nazwał „społeczeństwem multikonfliktowym" ${ }^{40}$. Manuel Canduela z Narodowej Demokracji z Hiszpanii demokrację liberalną uznał za „truciznę bardziej śmiertelną niż komunizm”41. Narodowodemokratyczna Partia Niemiec określiła integrację imigrantów z Niemcami „mordem na narodzie” i zaproponowała im nie wydalenie z kraju, ale powrót do domu ${ }^{42}$. Litewscy nacjonaliści nazwali propagowanie na przykład homoseksualizmu „poważnym przestępstwem”, a zmianę płci „szarlatanerią” i „zbrodnią przeciwko ludzkości”43. Złoty Świt w Grecji elity określał mianem ,plutokratycznej oligarchii”, a członków grup internacjonalistycznych „bolszewicko-związkową oligarchią"44. Brytyjska Partia Narodowa dystrybuowała ulotki, wśród których jedna przedstawiała kontury Wielkiej Brytanii pokryte barwami jej flagi, na które spada bomba $\mathrm{z}$ napisem islam ${ }^{45}$. Ponadto informowała o muzułmańskich gangach pedofilów ${ }^{46}$, a Polaków porównywała do małp na usługach jej przeciwników politycznych ${ }^{47}$. Polscy nacjonaliści zaś głosili hasło „Europa dla białych, Afryka dla HIV"48. Znakiem ich kampanii przeciwko homoseksualizmowi było logo „Zakaz pedałowania".

${ }^{36}$ Kotleba - L'udová strana Naše Slovensko, 10 bodov za Naše Slovensko!, http://www. naseslovensko.net/ (dostęp: 23.09.2016).

37 Marine Le Pen: Europa Wolnych Narodów zastapi UE!, 15.11.2016, http://www.nacjonalista.pl/2016/11/15/marine-le-pen-europa-wolnych-narodow-zastapi-ue/ (dostęp: 2.11.2017).

38 Le Pen: Po Brexicie Wiosna Ludów jest nieunikniona, 5.07.2016, https://nacjonalizm.wordpress.com/2016/07/05/le-pen-po-brexicie-wiosna-ludow-jest-nieunikniona/ (dostęp: 2.11.2017).

39 Marine Le Pen: ,, Nie islam jest problemem, lecz jego widoczność”, 7.07.2013, https://euroislam.pl/marine-le-pen-nie-islam-jest-problemem-lecz-jego-widocznosc/? (dostęp: 2.01.2017).

40 Ibidem.

41 Wywiad z Manuelem Canduelą, liderem Democracia Nacional (przeprowadzony przez M. Kowalczyka, opublikowany w „Polsce Niepodległej” 23.03.2014), 5.06.2014, http://narodowcy.net/publicystyka/wywiad-z-manuelem-canduela-liderem-democracia-nacional (dostęp: 14.01.2017).

42 Nationaldemokratische Partei Deutschlands, op. cit.

43 Tautininkų sajunga, op. cit.

44 Golden Dawn, op. cit.

45 British National Party, Time for Action. Save Your Country, druk ulotny, [b.m.d.w.].

46 British National Party, Our Children Are Not Halal Meat, druk ulotny, [b.m.d.w.].

47 I. Kadłuczka, Rasiści na Wyspach: Polacy jak malpy, 12.05.2013, http://wyborcza. pl/1,76842,13897262,Rasisci_na_Wyspach_Polacy_jak_malpy.html (dostęp: 17.01.2017).

48 Apelacja, 21.01.20111, https://www.nop.org.pl/2011/01/21/gazeta-wyborcza-falszuje-wypowiedz-sedziow.html/apelacja/ (dostęp: 24.11.2019).

Studia nad Autorytaryzmem i Totalitaryzmem 42, nr 1, 2020

(C) for this edition by CNS 
Marek Jeziński, analizując symbole stosowane w polityce w kontekście nowych mediów, wymienił następujące ich funkcje:

— reprezentacji - obejmuje reprezentowanie zjawisk, osób czy miejsc za pomocą symbolicznego wyobrażenia, na przykład flagi;

— integrująca — dotyczy istotnych dla grupy wartości w kontekście ich grupotwórczego potencjału;

— delimitacyjna - obejmuje ramy wyznaczające granice grupy;

- mobilizująca - obejmująca działania związane z narzucaniem odbiorcom określonych zachowań ${ }^{49}$.

Takie funkcje pełnią także język i komunikowanie. Stosowane słowa, zwroty i określenia stanowią reprezentację grup nacjonalistów radykalnych i typów ich myślenia. Określają ich grupotwórczy potencjał i integrują ich. Tworzą także granice dla grup, do których wejście jest możliwe po procesie identyfikacji z myślą zakodowaną w języku. Wreszcie taki język służy mobilizowaniu do działań przeciwko wyznaczonemu wrogowi.

\section{Działania nielegalne i konflikty z prawem}

Politycznym radykałom nie są obce również działania pozaprawne. Nie stanowią one reguły w formach ich aktywności, ale nie są też ich pozbawione.

$\mathrm{W}$ środkach masowego przekazu o zasięgu ponadnarodowym w minionych dwóch dekadach relacjonowane były liczne wydarzenia potwierdzające niezgodną z prawem aktywność partii radykalnie nacjonalistycznych lub ich członków i zwolenników. W Grecji w 2013 roku po zabójstwie muzyka Killaha P., sympatyzującego z ruchem antyfaszystowskim, aresztowanych zostało kilkadziesiąt osób związanych ze Złotym Świtem ${ }^{50}$. Na Słowacji przywódca partii Nasza Słowacja Marian Kotleba był oskarżany o propagowanie ekstremizmu ${ }^{51}$, a członkowie jego partii organizowali ,patrole porządkowe” wyszukujące Romów ${ }^{52}$. Roberto Fiore, który w 1997 roku uczestniczył w zakładaniu Nowej Siły we Włoszech, w przeszłości był ścigany w związku z oskarżeniem dotyczącym zamachu terrorystycznego, co

49 M. Jeziński, Funkcje symboli w polityce a nowe media. Przypadek polskich wyborów prezydenckich 2010 r., [w:] Symboliczność w przestrzeni polityki. Między teoria i praktyka, red. J. Golinowski, F. Pierzchalski, Bydgoszcz 2011, s. 201-202.

50 Lider neonazistowskiej greckiej partii Złota Jutrzenka opuścił areszt, 20.03.2015, http:// telewizjarepublika.pl/lider-neonazistowskiej-greckiej-partii-zlota-jutrzenka-opuscil-areszt,18525. html (dostęp: 25.11.2019); Grecja: Ruszyt proces działaczy Złotego Świtu, 7.02.2015, http://autonom.pl/?p=11053 (dostęp: 25.11.2019).

51 M. Kokot, Marian Kotleba, przywódca słowackich faszystów, z zarzutem propagowania ekstremizmu, 7.08.2018, https://www.euractiv.pl/section/demokracja/news/marian-kotleba-przywodcaslowackich-faszystow-z-zarzutem-propagowania-ekstremizmu/ (dostęp: 4.03.2020).

52 M. Kokot, Faszyści na patrolu, 20.08.2016, https://wyborcza.pl/1,76842,20572795,faszysci-na-patrolu.html?disableRedirects=true (dostęp: 4.03.2020).

Studia nad Autorytaryzmem i Totalitaryzmem 42, nr 1, 2020

(C) for this edition by CNS 
było przyczyną jego ucieczki z kraju w 1980 roku. Po przedawnieniu się sprawy był w latach 2008-2009 posłem do Parlamentu Europejskiego, zastąpił na tym stanowisku Alessandrę Mussolini — wnuczkę Benita Mussoliniego ${ }^{53}$. Fiore, przebywając w Wielkiej Brytanii, prowadził wspólne przedsięwzięcia z brytyjskim nacjonalistą Nickiem Griffinem. Griffin zaś od 1999 roku był przewodniczącym Brytyjskiej Partii Narodowej. W 2004 roku został aresztowany pod zarzutem podżegania do nienawiści rasowej. W 2005 roku został oskarżony o wykroczenia polegające na użyciu słów lub zachowań mających lub mogących wywołać nienawiść rasową; został oczyszczony z zarzutów w 2006 roku $^{54}$.

To wybrane przykłady konfliktów nacjonalistów z prawem i oskarżeń kierowanych wobec nich. Niektóre z nich są potwierdzeniem myślenia gnostycznego, zgodnie z którym cel stawiany jest ponad moralność, inne zaś, jak na przykład zorganizowana przestępczość Złotego Świtu, o którą partia była oskarżana, są zaprzeczeniem wzorca ,politycznych żołnierzy”, propagowanego przez nacjonalistów.

\section{Roszczenia terytorialne i zagrożenie nową wojną w Europie}

Demokracje to państwa, systemy i sposoby myślenia, dla których wartością jest pokój. Państwa demokratyczne z reguły nie prowadzą z sobą wojen. Tymczasem programy przyjmowane przez partie i organizacje zrzeszające radykalnych nacjonalistów zawierają oficjalne żądania dotyczące roszczeń terytorialnych bądź w wypowiedziach i aktywności polityków tych partii „przemycane” są ukryte postulaty rewizji granic we współczesnej Europie.

Przykładem może być Narodowodemokratyczna Partia Niemiec, która uznała, że roszczenia narodu niemieckiego do całej ziemi niemieckiej należy utrzymywać i nie można rezygnować z roszczeń do Sudetów i „Niemiec Wschodnich”55, czyli obszarów, które znalazły się między innymi w granicach Polski. Przyłączenie Niemieckiej Republiki Demokratycznej w 1990 roku do Republiki Federalnej Niemiec partia ta określała jako pierwszy etap zjednoczenia; pełne zjednoczenie

53 R. Wodak, The Politics of Fear. What Right-Wing Populist Discourses Mean, Los Angeles-London-New Delhi 2015, s. 199; I. Cobain, M. Taylor, Language school run by Italian fascist leader, 29.02.2008, https://www.theguardian.com/politics/2008/feb/29/thefarright.italy (dostęp: 25.11.2019); Ł. Woźnicki, Winnicki zabrat do Sejmu delegację neofaszystów z włoskiej Forza Nuova, 11.11.2015, http://wyborcza.pl/1,75398,19170675,winnicki-zabral-do-sejmu-delegacje-neofaszystow-z-wloskiejforza.html (dostęp: 25.11.2019); Parlament Europejski, Postowie do PE - Roberto Fiore, http://www. europarl.europa.eu/meps/pl/41004/ROBERTO_FIORE_home.html (dostęp: 4.12.2016).

54 „The Telegraph”, Nick Griffin, https://www.telegraph.co.uk/news/uknews/1399674/Nick-Griffin.html (dostęp: 25.11.2019).

55 P. Maćkowiak, Narodowo-Demokratyczna Partia Niemiec. Wizerunek partii neofaszystowskiej, Warszawa 1983, s. 46.

Studia nad Autorytaryzmem i Totalitaryzmem 42, nr 1, 2020

(C) for this edition by CNS 
miało się dokonać po włączeniu „Niemiec Wschodnich”56. Natomiast partia Ojczyzna w Rosji postulowała wprowadzenie przepisów dotyczących możliwości prowadzenia niezależnej polityki w historycznie ważnych dla Rosji regionach oraz integrację terytoriów eurazjatyckich, będących w przeszłości częścią Związku Radzieckiego i Cesarstwa Rosyjskiego ${ }^{57}$. Postulaty zmiany granic charakteryzowały też partie nacjonalistyczne na Bałkanach, czego przykładem może być Serbska Partia Radykalna ${ }^{58}$, a w ukraińskim nacjonalizmie tliły się pretensje do południowo-wschodniej części Polski ${ }^{59}$.

Wymienionych postulatów, choć wydawać się one mogą fantasmagorią, nie należy jednak ignorować. Historia była już świadkiem ignorancji wobec idei, pomysłów i ludzi, którzy stawali się zarzewiem konfliktów i wojen. Szczególnie przykład niedawnej wojny w Jugosławii pozostaje w pamięci, a wezwanie serbskich nacjonalistów do restauracji Wielkiej Serbii wzbudza silne emocje.

\section{Zakończenie}

Nacjonalistyczne oceny demokracji liberalnej, koncepcja wolności i suwerenności narodowej, totalitarny i gnostyczny typ myślenia, język komunikowania, działania nielegalne i konflikty z prawem, postulaty terytorialne i zagrożenie nową wojną w Europie - traktowane łącznie — są symptomatami antydemokratyzmu partii radykalnie nacjonalistycznych. Choć można być demokratą zachowującym przekonania antyunijne, to nie można być demokratą posługującym się myśleniem gnostycznym, zgodnie z którym Unia Europejska traktowana jest jako wróg, a jej obszar jako świat identyfikowany ze złem. Nie da się pogodzić także języka nienawiści z postawami demokratycznymi, lecz symptomat ten można poszerzyć także na reprezentantów innych partii politycznych. Interpretowanie idei wolności w kategoriach negatywnych i kolektywnych nie może być pozbawione indywidualnych predylekcji wolnościowych właściwych demokracji. Roszczenia terytorialne są natomiast zakwestionowaniem międzynarodowego ładu politycznego, który po zakończeniu zimnej wojny jest podstawą pokoju w Europie.

Myśl nacjonalistyczna interpretowana radykalnie, a także wybrane przejawy aktywności partii oraz innych organizacji nacjonalistycznych mogą świadczyć o deficytach ich demokratyczności. Nie znaczy to, że pojedyncze partie cechuje

56 I. Janicka, Niemieckie partie polityczne. Vademecum, Piła 2008, s. 70.

57 Partija „Rodina”, Za Rodinu i dostojnuju zhizn'! Social'nyj antikrizisnyj plan „Rodiny”, [w:] Predwybornaja programma Partji ,,Rodina”. Al'ternativa dlja naroda Rossji (Projekt), http:// www.rodina.ru/partiya/documents (dostęp: 28.11.2016).

58 Srpska radikalna stranka, op. cit.

59 T. Baliszewski, „Polska powinna oddać nam Przemyśl”. Ukraińscy nacjonaliści zgłaszaja roszczenia terytorialne, 30.01.2014, http://natemat.pl/90333,polska-powinna-oddac-nam-przemyslukrainscy-nacjonalisci-zglaszaja-roszczenia-terytorialne (dostęp: 22.09.2016).

Studia nad Autorytaryzmem i Totalitaryzmem 42, nr 1, 2020

(C) for this edition by CNS 
antydemokratyzm myśli i działalności potwierdzony symptomatami występującymi łącznie. Symptomaty te świadczą o tendencji właściwej myśli i rodzinie politycznej radykalnego nacjonalizmu. Należy jednak wyjaśnić, że myśl tych organizacji, w tym krytyka demokracji i cele, a także retoryka, formułowane na etapie walki o poparcie społeczne, mogą różnić się od myśli realizowanej i retoryki stosowanej po osiągnięciu celu w postaci zwycięskiej elekcji lub zdolności rządzenia. Warto też dodać, że za sprawą krytyk formułowanych przez radykalnych nacjonalistów wobec demokracji teza o możliwości występowania deficytów demokracji we współczesnych systemach politycznych, formułowana w programach i aktywności organizacji radykalnie nacjonalistycznych, powinna stanowić przyczynek do refleksji o jakości współczesnej demokracji i jej przyszłości.

\section{Bibliografia}

Apelacja, 21.01.20111, https://www.nop.org.p1/2011/01/21/gazeta-wyborcza-falszuje-wypowiedz-sedziow.html/apelacja/ (dostęp: 24.11.2019).

Baliszewski T., „Polska powinna oddać nam Przemyśl”. Ukraińscy nacjonaliści zgłaszaja roszczenia terytorialne, 30.01.2014, http://natemat.pl/90333,polska-powinna-oddac-nam-przemysl-ukrains cy-nacjonalisci-zglaszaja-roszczenia-terytorialne (dostęp: 22.09.2016).

Bäcker R., Nietradycyjna teoria polityki, Torun 2011.

Bartyzel J., Między katolickim panhiszpanizmem a separatyzmem etnicznym i suwerenizmem. Aporematyczność pojęcia ,nacjonalizm” w Hiszpanii, [w:] Wspótczesne nacjonalizmy, red. M. Jeziński, Torun 2008.

British National Party, Our Children Are Not Halal Meat, druk ulotny, [b.m.d.w.].

British National Party, Time for Action. Save Your Country, druk ulotny, [b.m.d.w.].

Cobain I., Taylor M., Language school run by Italian fascist leader, 29.02.2008, https://www.theguardian.com/politics/2008/feb/29/thefarright.italy (dostęp: 25.11.2019).

Democracia Nacional, Programa Democracia Nacional, [w:] Documentos Ideológicos y Programáticos de Democracia Nacional, http://democracianacional.org/dn/conocenos/ (dostęp: 27.10. 2016).

Durska A., Podwójna jaźń polskiego nacjonalizmu, [w:] Paradoksy polityki, red. M. Karwat, Warszawa 2007.

Eco U., Ur-fascism, „The New York Review of Books” 22.06.1995.

Fiore R., Sumienie europejskie i totalitaryzm, wypowiedź w debacie w Parlamencie Europejskim, Strasburg, 25.03.2009, http://www.europarl.europa.eu/sides/getDoc.do?pubRef=//EP//TEXT+ $\mathrm{CRE}+20090325+\mathrm{ITEM}-010+\mathrm{DOC}+\mathrm{XML}+\mathrm{V0} / / \mathrm{PL} \&$ language $=$ pl\&query $=$ INTERV \&detail=3-392 (dostęp: 17.01.2017).

Forza Nuova, 8 Punti, http://www.forzanuova.eu/?page_id=542 (dostęp: 4.12.2016).

Forza Nuova, Chi siamo, http://www.forzanuova.eu/?page_id=103 (dostęp: 4.12.2016).

Front National, Notre Projet - Programme Politique du Front National, 2012, http://www.frontnational.com/le-projet-de-marine-le-pen/ (dostęp: 28.06.2016).

Garlicki J., Komunikowanie polityczne - od kampanii wyborczej do kampanii permanentnej, „Studia Politologiczne" 16, 2010.

Golden Dawn, What Being a Golden-Dawner Means, http:/www.xryshaygh.com/en/information (dostęp: 28.06.2016). 
Grecja. Ruszyt proces działaczy Złotego Świtu, 7.02.2015, http://autonom.pl/?p=11053 (dostęp: 25.11.2019).

Janicka I., Niemieckie partie polityczne. Vademecum, Piła 2008.

Jeziński M., Funkcje symboli w polityce a nowe media. Przypadek polskich wyborów prezydenckich 2010 r., [w:] Symboliczność w przestrzeni polityki. Między teoria i praktyka, red. J. Golinowski, F. Pierzchalski, Bydgoszcz 2011.

Jobbik Magyarországért Mozgalom, Alapitó Nyilatkozat, 24.10.2003, https://jobbik.hu/rovatok/egyeb/ alapito_nyilatkozat (dostęp: 14.02.2017).

Kadłuczka I., Rasiści na Wyspach: Polacy jak matpy, 12.05.2013, http://wyborcza.pl/1,76842,1389 7262,Rasisci_na_Wyspach_Polacy_jak_malpy.html (dostęp: 17.01.2017).

Karwat M., Kryteria demokratyzmu postaw społecznych, stosunków politycznych i państwa, „Społeczeństwo i Polityka" 1 (2), 2005.

Kokot M., Faszyści na patrolu, 20.08.2016, https://wyborcza.pl/1,76842,20572795,faszysci-na-patrolu.html?disableRedirects=true (dostęp: 4.03.2020).

Kokot M., Marian Kotleba, przywódca słowackich faszystów, z zarzutem propagowania ekstremizmu, 7.08.2018, https://www.euractiv.pl/section/demokracja/news/marian-kotleba-przywodcaslowackich-faszystow-z-zarzutem-propagowania-ekstremizmu/ (dostęp: 4.03.2020).

Kotleba — L'udová strana Naše Slovensko, 10 bodov za Naše Slovensko!, http://www.naseslovensko. net/ (dostęp: 23.09.2016).

Le Pen J.M., Nadzieja. Rozważania o Francji i Europie z przywódca francuskiego Frontu Narodowego, przeł. M. Miszalski, Warszawa 1994.

Le Pen: Po Brexicie Wiosna Ludów jest nieunikniona, 5.07.2016, https://nacjonalizm.wordpress. com/2016/07/05/le-pen-po-brexicie-wiosna-ludow-jest-nieunikniona/ (dostęp: 2.11.2017).

Lewandowski M., Na szlaku idei. Nacjonalizm Narodowego Odrodzenia Polski w świetle publikacji pisma ,Szczerbiec”, Warszawa 2014.

Lider neonazistowskiej greckiej partii Złota Jutrzenka opuścit areszt, 20.03.2015, http:/telewizjarepublika.pl/lider-neonazistowskiej-greckiej-partii-zlota-jutrzenka-opuscil-areszt,18525.html (dostęp: 25.11.2019).

Maćkowiak P., Narodowo-Demokratyczna Partia Niemiec. Wizerunek partii neofaszystowskiej, Warszawa 1983.

Malendowicz P., Radykalna myśl polityczna a bezpieczeństwo europejskich demokracji. Przykład nacjonalizmu antysystemowego, „Rocznik Integracji Europejskiej” 13, 2019.

Malendowicz P., W drodze do władzy... Nacjonalistyczne projekty państw Europy XXI wieku, Bydgoszcz 2017.

Marine Le Pen: Europa Wolnych Narodów zastapi UE!, 15.11.2016, http://www.nacjonalista. pl/2016/11/15/marine-le-pen-europa-wolnych-narodow-zastapi-ue/ (dostęp: 2.11.2017).

Marine Le Pen: „,Nie islam jest problemem, lecz jego widoczność”, 7.07.2013, https://euroislam.pl/ marine-le-pen-nie-islam-jest-problemem-lecz-jego-widocznosc/? (dostęp: 2.01.2017).

Movimiento Social Republicano, Programa político. 300 medidas para cambiar España, http://msr. org.es/nosotros/programa-politico (dostęp: 11.12.2016).

Narodowe Odrodzenie Polski, Zasady programowe, http://www.nop.org.pl/zasady-programowe/ (dostęp: 25.11.2019).

Nationaldemokratische Partei Deutschlands, Arbeit. Familie. Vaterland. Das Parteiprogramm der Nationaldemokratischen Partei Deutschlands, http://www.npd.de/themen/ (dostęp: 9.12.2014).

Obóz Narodowo-Radykalny, Deklaracja ideowa, https://www.onr.com.pl/deklaracja-ideowa/ (dostęp: 16.01.2017).

Parlament Europejski, Postowie do PE - Roberto Fiore, http://www.europarl.europa.eu/meps/ pl/41004/ROBERTO_FIORE_home.html (dostęp: 4.12.2016). 
Partija „Rodina”, Za Rodinu i dostojnuju zhizn’! Social'nyj antikrizisnyj plan „Rodiny”, [w:] Predwybornaja programma Partji „Rodina”. Al'ternativa dlja naroda Rossji (Projekt), http://www. rodina.ru/partiya/documents (dostęp: 28.11.2016).

Pravyi sektor, Programa partii „Pravyi sektor”, http://pravyysektor.info/programa.html (dostęp: 22.09.2016).

Radomski G., Puryfikacja czy instrumentalizacja? Narodowe Odrodzenie Polski wobec kanonu kultury narodowej, [w:] Wspótczesne nacjonalizmy, red. M. Jeziński, Toruń 2008.

Srpska radikalna stranka, Program, http://www.srpskaradikalnastranka.org.rs/program/44 (dostęp: 7.01.2015).

Stowarzyszenie „Nigdy Więcej”, Brunatna Księga, https://www.nigdywiecej.org/brunatna-ksiega (dostęp: 25.11.2019).

Tautininkų sajunga, Bendroji programa, http://www.tautininkai.lt/programos/bendroji-programa-2016-m/ (dostęp: 19.09.2016).

„The Telegraph”, Nick Griffin, https://www.telegraph.co.uk/news/uknews/1399674/Nick-Griffin.html (dostęp: 25.11.2019).

Wodak R., The Politics of Fear. What Right-Wing Populist Discourses Mean, Los Angeles-LondonNew Delhi-Singapore-Washington, DC 2015.

Woźnicki Ł., Winnicki zabrat do Sejmu delegację neofaszystów z włoskiej Forza Nuova, 11.11.2015, http://wyborcza.pl/1,75398,19170675,winnicki-zabral-do-sejmu-delegacje-neofaszystow -z-wloskiej-forza.html (dostęp: 25.11.2019).

Wywiad z Manuelem Canduelą, liderem Democracia Nacional (przeprowadzony przez M. Kowalczyka, opublikowany w „Polsce Niepodległej” 23.03.2014), 5.06.2014, http://narodowcy.net/publicystyka/wywiad-z-manuelem-canduela-liderem-democracia-nacional (dostęp: 14.01.2017). 